\title{
A dialogue of the deaf? The health impacts of globalisation
}

Opinion about the true impacts on human health of globalisation remains sharply divided. On the one hand, a wide range of health professionals, non-governmental organisations (NGOs), scholars and activists fear globalisation is worsening the divide between haves and have nots to unprecedented degrees. ${ }^{1}$ As globalisation processes are being played out, they argue that this is leading to real impoverishment, economic insecurity and reduced life chances for those being left behind what Friedman calls a "winner take all" system. ${ }^{2}$ There is little hope, they argue, for a real sharing of the largesse of globalisation without fundamental changes to the nature of the system itself. On the other hand, many others have much hope that globalisation is ultimately a positive force for the betterment of all. By enabling greater generation of wealth, it is believed that globalisation will lead to technological innovation, dissemination of information and know how, adoption of minimal ethical, environmental and labour standards, and eventually increased standards of living worldwide. It is through these processes that real improvements in human health will be realised. While there are admittedly wrinkles to be ironed out along the way to such global prosperity, a "steady as she goes" fortitude will gradually lead us to a better world.

The distance between these two perspectives on globalisation could not be farther apart. As the two polarised arguments are played out in meetings like the People's Health Assembly in Dhaka, Bangladesh and the World Economic Summit in Davos, Switzerland, one observes a dialogue of the deaf in which both sides are entrenched in the rightness of their views. Firmly in the driver's seat of globalisation at present are the optimists who, advantaged by economic and other resources, mobility, global communications and, above all, formal positions of power, do not feel so strongly the need to question the possibility that there may be flaws in their paradigm. Far more numerous, but clearly out resourced and out voiced, are the pessimists who see globalisation as the latest, and possibly final, phase of wholescale colonisation of the world by certain dominant interests. As long as the debate remains so highly polarised, it is difficult to know who is right and, more importantly, how to move forward?

Blanket celebrations or condemnations of globalisation are neither accurate nor constructive. The current period of "full-scale globalisation" from the 1960s onwards" is part of a longer historical process, one that is neither linear, progressive or predetermined. Yet, it is also a distinct period in human history, defined by unparalleled technological changes that are bringing many of us closer together in unprecedented ways. Globalisation is both old and new.

One option is to accept that globalisation, as presently being played out, will unavoidably create a world of irreconciliable interests. Efforts to bring together such diverse perspectives are invariably doomed by the zero-sum game globalisation represents. A fundamental rebuilding or even replacing of the globalisation machine, as compared with mere tinkering, would perhaps change the current configuration of winners and losers, but a new set of inequities are likely to be created in the process. What, therefore, is the alternative?

The second option, which both sides seem in principle to be searching for, is to find some middle ground where the rough edges of globalisation are smoothed out. Both sides of the debate remain disengaged and need to begin building bridges. What are the challenges for public health? Firstly, we need to recognise and understand far better the micro-macro linkages between globalisation and the health of specific individuals and population groups. Baum ${ }^{1}$ reports on the strong feelings expressed in Dhaka that the terrible experiences of recent years in many millions of people's lives are attributable to globalisation. The empirical evidence that she cites, however, is limited, and she rightly points to the all important need for more efforts in this direction. Railing against globalisation without such evidence will generally fall on deaf ears. This requires going beyond traditional approaches to public health research, beginning with means of capturing the transnational nature of many health determinants and outcomes.

Secondly, we need to translate this evidence into concrete and feasible ideas for policy change. Scrapping the entire global economy is not such an idea. To encourage Seattle-like changes without workable alternatives would be like risking the Dark Ages after the fall of the Roman Empire. Again, Baum touches on concrete policy responses although these need far greater specification. Building into the global economy strong protection for the weak and vulnerable, mechanisms for generating enough resources for social and environmental protection, governance structures that ensure violations of accepted standards of practice are brought to book all need to be defined. Some policy changes are already happening ${ }^{4}$ albeit on a small scale and probably without sufficient teeth. New initiatives to improve corporate social responsibility, for example, are leading to greater reflection on the wider social and environmental impacts of global economic activity. Many see this as an encouraging sign that those at the top are neither oblivious nor uncaring about such issues. How do we harness these good intentions more effectively?

Finally, we need to engage in a true debate that breaks down the existing polarised views. The events in Seattle in late 1999 certainly grabbed the attention of those driving globalisation, but it amounted to the equivalent of slashing their tyres or stealing the car radio, rather than redirecting the route of the vehicle. The immediate response has been increased security. It would be far more effective to demonstrate that the globalisation road is one full of potholes and sharp turns. This requires going beyond moral hair pulling to play smart, appealing to utilitarian arguments where need be. The Asian financial crisis is a case in point. It sent panic across the world's financial institutions (including both small and large investors), bringing home the lesson that contagion is global. The "I love you" computer virus that spread from the Philippines to disrupt computers worldwide within days again draws on health imagery to illustrate that globalisation brings opportunities and risks. In short, the public health community needs to get far smarter politicallyassembling the evidence, defining the policy alternatives, and selling them in the right circles. Global health is public health writ large.

Centre on Globalisation, Environmental Change and Health,

London School of Hygiene and Tropical Medicine, London

(kelley.lee@lshtm.ac.uk)

1 Baum F. Health, equity, justice and globalisation: some lessons from the People's Health Assembly. F Epidemiol Community Health 2001;55:613-6.

2 Friedman T. The lexus and the olive tree. New York: HarperCollins, 2000.

3 Scholte JA. Globalization, a critical introduction. London: Macmillan Press, 2000.

4 Schwartz P, Gibb B. When good companies do bad things. Responsibility and risk in an age of globalization. New York: John Wiley, 1999. 